日臨外会誌 $67(6), 1181-1185,2006$

原著

開胸経横隔膜的 Hassab 手術の検討一開腹手術との比較一 富山大学第 2 外科

坂東正長田拓哉山岸文範塚田一博

食道胃静脈瘤に対する開胸経横隔膜アプローチの Hassab 手術（TTP） と開腹による Hassab 手術 (AP) との比較検討を行ったので報告する. 2000年から2003年までに施行 したTTP群13例を対象として AP 群22例と比較した。手術時間はTTP群で有意に延 長していた. 出血量と輸血量はTTP 群で有意に少なかった。摘出脾重量は両群間に差は なく巨脾による経横隔膜的手技の制約はなかった。TTP 群では 3 例 $23.1 \%$ に等度の 合併症が認められたが両群とも重篤なものはなく合併症発生率に差はなかった. 術後在 院日数は平均31日でTTP 群が短い傾向であった．肝機能に与える影響を総ビリルビン 値の推移で比較したが差は認められなかった。侵襲の程度の比較として白血球数と IL-6 の変動を検討したが比較的軽度と考えられた。術後 5 年累積再発率はTTP 群が9.1\%で AP 群の 22.3\%よりやや低かった。開胸経横隔膜的手技によるHassab 手術は開腹によ る手技と比べ安全で治療効果の改善が期待できる術式と考えられた。

索引用語：食道胃静脈瘤，Hassab 手術，開胸経横隔膜的手術

緒言

食道胃静脈瘤に対する治療は背景肝疾患に伴うリス クの高さから近年ては手術治療にかわり内視鏡治療や IVRが主流となってきだ)-31. しかしながらこれらの 治療に抵抗を示す症例や，肝予備能が良好な症例に対 して手術治療が良い適応となる場合もあり有用な手段 の一つと考えられる゙．2000年よりわれわれは開胸経 横隔膜アプローチにて Hassab 手術を施行してい $3^{5) 6)}$. 良好な視野での脾門の処理や食道の血行遮断に 関してのアドパンテージが開腹アプローチに対してあ ると考え採用している．今回われわれは本術式を開始 する以前に施行していた一般的な開腹による Hassab 手術との比較検討を行ったので報告する。

\section{対象および方法}

2000年から2003年までにわれわれの施設で食道胃静 脈瘤に対して開胸経横隔膜アプローチによる Hassab 手術を施行した13例 (以下TTP : thoraco - trans phrenic procedure 群) を対象とした，比較対照群を 1980年から1996年に開腹アプローチ（以下 AP:

2006年 1 月 10 日受付 2006 年 4 月 5 日採用

〈所属施設住所〉

○930-0194＼cjkstart富山市杉谷2630 abdominal procedure 群）にて施行した22例とした。 開胸経横隔膜的手術は, 分離挿管下に右側臥位で第 7 肋間開胸後横隔膜を切開し腹腔内に達するアプロー チで脾摘および胃上部血行遮断を行い，食道下部の血 行遮断時には腹腔側からと胸膜切開を加之胸腔内から も操作を行った ${ }^{6)}$.

術後再発率は Kaplan-Meier 法を用いて算出し， 2 群間の統計学的検定は generalized Wilcoxon test, 力 イ二乗検定およびMann WhitneyのU 検定を用い， $\mathrm{p}<0.05$ を有意差ありとした．統計解析ソフトウエア として Stat View ver.5.0J を用いた.

$$
\text { 結 果 }
$$

\section{1. 患者背景の検討 (Table 1)}

$\mathrm{TTP}$ 群の平均年齡は53.1歳で AP 群の55.7歳と差 は認められなかった。 TTP 群は男性 9 例女性 4 例で, 14例および8例であった AP 群との間に性別の差は認 められなかった。背景疾患では TTP 群が全13例とも 肝硬変であったのに対して AP 群では肝硬変は16例で 他の特発性門脈圧元進症が 5 例と慢性肝炎が 1 例認め られ，有意に肝硬変の比率が高かったが，ICG テスト は差を認めず, Child-Pugh score は TTP群が平均 $5.8 て ゙ \mathrm{AP}$ 群の6.4に比べ各項目別にも有意差は認めら れずむしろ良好な傾向であった. 
Table 1 Patients' characteristics of the two groups

\begin{tabular}{lccc} 
Group & TTP(13) & AP(22) & P value \\
\hline Age(Average) & 53.1 & 55.7 & 0.37 \\
Sex (male/female) & $9 / 4$ & $14 / 8$ & 0.74 \\
Diagnosis & & & \\
$\quad$ liver cirrhosis & 13 & 16 & 0.04 \\
$\quad$ idiopathic portal hypertension & 0 & 5 & \\
$\quad$ chronic active hepatitis & 0 & 1 & \\
ICG R15 $^{2}$ ) & 33 & 24 & 0.11 \\
Child-Pugh score & 5.8 & 6.4 & 0.12 \\
ascites (score) & 1.00 & 1.38 & 0.11 \\
encepharopathy (score) & 1.00 & 1.05 & 0.82 \\
PT (\%) & 75.2 & 69.4 & 0.23 \\
TB(mg/dl) & 0.87 & 1.19 & 0.45 \\
Albumin(g/dl) & 3.65 & 3.61 & 0.72 \\
\hline
\end{tabular}

Table 2 Comparison of factors about surgical stress between two groups

\begin{tabular}{lccc} 
Group & TTP & AP & P value \\
\hline Operation time (min) & $444(285-605)$ & $252(170-340)$ & 0.0001 \\
Operative blood loss $(g)$ & $851(265-1980)$ & $2039(410-4520)$ & 0.0003 \\
Blood transfusion & & & \\
MAP $(\mathrm{ml})$ & $524(0-1400)$ & $1120(0-2962)$ & 0.003 \\
FFP $(\mathrm{ml})$ & $357(0-1280)$ & $1111(0-4970)$ & 0.03 \\
No BTF cases & 4 & 1 & 0.03 \\
$\quad$ (MAP $=0 \mathrm{ml} / \mathrm{FFP}=0 \mathrm{ml})$ & $(5 / 7)$ & $(1 / 3)$ & \\
Weight of the spleen $(\mathrm{g})$ & $548(215-1330)$ & $446(130-760)$ & 0.51 \\
\hline
\end{tabular}

\section{2. 術中所見に関する検討（Table 2)}

手術時間は TTP 群が平均444 (285-605) 分で AP 群 の252 (170-340) 分に比べ有意 $(\mathrm{p}<0.0001)$ に延長し ており, TTP 群のデメリットと考えられた。しかしな がら手術時出血量は TTP 群で851 (265-1980) g と AP 群の2,039 (410-4520) $\mathrm{g}$ に比べ有意 $(\mathrm{p}<0.0005)$ に少 なく、それに伴って輸血量もTTP群では MAP が $524(0-1400) \mathrm{ml}$, FFP が357 (0-1280) ml と AP 群 の MAP $1,120(0-2962) \mathrm{ml}$ と FFP $1,111(0-4970)$ $\mathrm{ml}$ に比べ有意（ $\mathrm{p}<0.05 ） に$ 減少していた。 また，無 輸血症例が TTP 群では 4 例あり AP 群の1例のみに 比べ多い傾向 $(\mathrm{p}<0.05)$ がみられた。摘出した脾葴の 重量には両群間に差は認められず，TTP 群では最大 $1,330 \mathrm{~g}$ であったが脾腫の程度による経横隔膜的手技 の制約はなかった。

\section{3．術後合併症の検討 (Table 3)}

両群とも再手術や死亡に至るような重篤な合併症は 認められなかった，TTP 群では 3 例 $23.1 \%$ に中等度

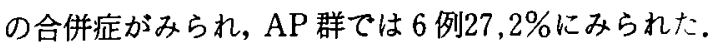

統計学的な差は認められないものの, TTP 群でやや 少ない傾向であった，TTP 群の合併症 3 例の内訳は, 要延する胸水が 2 例にみられ，血友病を合併していた 1 例に主に血友病に伴う凝固因子低下が原因と考えら れる背部の創皮下出血がみられやや治療に難渋した。 開胸操作に伴う肺炎などの呼吸器合併症も危惧された が特に認められなかった。また AP 群ではみられたイ レウスも腹腔内操作の少ない TTP 群では発生はみら れなかった。

\section{4. 術後経過の検討 (Table 4)}

在院死亡は両群ともに 1 例も認められなかった。術 後在院日数は, TTP 群で平均31日と AP 群の53日に 比べ有意（ $p<0.05 ）$ に短い傾向がみられた。TTP群 では術後28日目の退院を原則として設定しているが, 胃癌合併による胃部分切除を施行した症例が経口搨取 開始時期を遅らせて管理したため44病日と延長したの を最高として, 出血源不明の上部消化管出血と皮下出 血を術後に認めた症例で在院期間が若干延長した。術 式別の肝機能に与える影響を検討するために，総ビリ 
Table 3 Comparison of postoperative complications between two groups

\begin{tabular}{lccc} 
Group & TTP & AP & P value \\
\hline Postoperative complications & $23.1(3 / 13)$ & $27.2(6 / 22)$ & 0.78 \\
ileus & 0 & 1 & \\
gastric perforation & 0 & 1 & \\
subphrenic abscess & 0 & 1 & \\
pleural effusion & 2 & 1 & \\
uncontrollable ascites & 0 & 1 & \\
pneumonia & 0 & 1 & \\
subcutaneous hemorrhage & 1 & 0 & \\
\hline
\end{tabular}

Table 4 Comparison of postoperative course between two groups

\begin{tabular}{lccc} 
Group & TTP & AP & P value \\
\hline Hospital mortality (\%) & 0 & 0 & \\
Post operative hospital stay (day) & $31(24-44)$ & $53(16-140)$ & 0.02 \\
WBC elevation rate & 4.1 & 5.3 & 0.22 \\
$\quad$ PPOD WBC $\left(/ \mathrm{mm}^{3}\right)$ & 10913 & 14153 & 0.13 \\
TB elevation rate & 2.0 & 3.0 & 0.79 \\
Post operative max. TB $(\mathrm{mg} / \mathrm{dl})$ & 1.8 & 3.2 & 0.009 \\
\hline
\end{tabular}

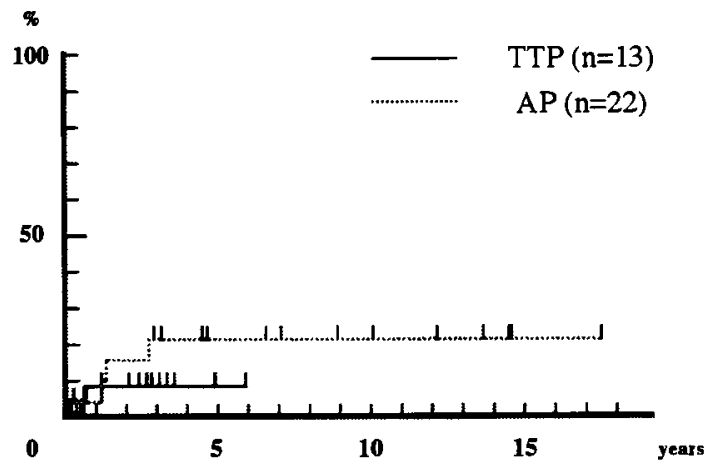

Fig. 1 : Accumulation recurrence rate according to the operation methods

ルビン值の変動を比較した。最高值の平均では AP 群 が有意に高く不良な傾向がみられたが，術前値に対す る術後最高值の上昇率に関しては両群に統計学的な有 意差は認められなかった。術式別の全身に与える侵襲 の程度の比較として白血球の変動を検討した．第 1 病 日における白血球数と, 術前値からの上昇の比率は TTP 群でやや低い傾向がみられたものの統計学的な 有意差は認められなかった。その他 TTP 群で術後の IL-6の変動を検討したが第 1 病日に平均 $128 \mathrm{pg} / \mathrm{ml}$ と ピークに達し，その後比較的速やかに低下し第 3 病日
には $45 \mathrm{pg} / \mathrm{ml}$ と著明に減少した。

5. 再発率の検討 (Fig. 1)

術後 5 年累積再発率はTTP 群が9.1\%で AP 群が $22.3 \% て ゙ あ り$, 観察期間が短くまた統計学的な有意差 はないものの, TTP 群は少なくとも AP 群と同等以 上の治療成績であると考えられた。

$$
\text { 考察 }
$$

食道胃静脈瘤は末期肝硬変に発症することが多くそ の治療に際しては肝予備能が不良であることなどから 種々の制約を伴う。そのため治療の主役は1978年に高 瀨らが硬化療法を導入して以来, 特に80年代中盤以降 は手術から侵襲の少ない内視鏡治療へと移行した7. 特に安全性を最重点に置いた治療法として手術が他の 治療法に移り変わったのであるが，仮に安全性が保た れる術式であれば病態が複雑な門脈圧六進症症例の中 には手術適応となる症例が存在すると考えられる。

手術手技上最も注意を要するのは疾患の性質上出血 に対する問題であるが，われわれの施行している術式 における長所はこの点にあると考えている。多種ある 原疾患のため全例無輸血手術が可能とは限らないが, 出血量の㧕制は術後肝不全の予防の点からは非常に重 要なことである. 出血の抑制は出血しやすい部位をい かに避けて通り, 止血操作をいかに確実に行うかが重 
要と考えられるが, 本術式では側副血行路の豊富な腹 壁や腹腔内を通過せず治療部位に到達できることと， 特に脾門部を中心とした良好な視野のもと脾摘や胃上 部周囲の血行遮断が安全に行えることが開腹手技に比 べ優れている点と考えられる．さらに安全であること は, 延いては十分なそして確実な血行遮断ができるこ とにつながり, 治療効果も上がると考えられる.した がって, 本研究は後向き研究であり䦕腹手技は古い症 例のため全般的に手技が向上した最近の手術に比べ成 績が若干不良となっていることも考慮しなければなら ないが，比較すると本術式は出血量が少なく, 再発率 も少ない手術である可能性が示唆された。

開腹術に比べ開胸を伴う術式の場合に危惧される合 併症は呼吸器に関するものであるが，今のところほと んど経験しておらず，中等度の胸水が 2 例に観察され ているが，いずれの症例においても外来通院の頃には 消失している．また一部の症例で術前後の呼吸機能の 変化に関しての検討を行ったが, 術後 1 力月位の時期 には\% FVCが15から25ポイント程度低下したもの の,FEV 1.0\%はほとんど変化しなかった. その他開胸 時に第 8 もしくはその前後の助骨を 1 本のみ切離して いることによる疼痛が初期の症例で比較的みられてい たが，最近の症例では肋骨ピンを使用することにより 著明に改善した ${ }^{8)}$.

治療効果に関しては現時点での評価はやや良好とし かいえないものの, 今後本術式を続けるにあたり否定 されるようなデータはないと考えられた。門脈圧六進 症は重篤な疾患ではあるものの癌などの悪性疾患では なく 5 年程度の治療成績ではなく 10 年位の観察が必要 と考えられる ${ }^{9101}$. したがって術式の治療効果に関し ては今後長期的な検討を行う必要性があると思われる が 5 年再発率までの成績をみる限り長期的にも期待て きるものと考えられた。

\section{結語}

開胸経横隔膜的手技によるHassab 手術に関して検 討した. 一般的な開腹による手技と比べ安全で治療効 果の改善が期待できる術式と考えられた。

本論文の要旨の一部は, 第11回日本門脈圧元進症学会総 会（東京）にて発表した。

\section{文献}

1）高瀨靖広：食道静脈瘤治療の現況一内視鏡的硬化 療法手技一. Gastroenterol Endosc 47:58一65, 2005

2）小原勝敏：胃静脈瘤治療の現況一胃静脈㿔治療法 一. Gastroenterol Endosc $47: 356-365,2005$

3）松谷正一, 國分茂博, 中村健治：II門脈圧元進症. 税所宏光編, 肝・膵疾患の IVR 治療, MEDICAL VIEW, 東京, 2002, p78-117

4) 別府倫兄, 大橋 薰, 大浦慎祐他：食道胃静脈瘤 に対する直達手術一食道離断術と Hassab 術一。 日外会誌 $97: 55-63 ， 1996$

5) Hassab MA: Gastroesophageal decongestion and splenectomy. J Internat Coll Surgeons 41 : 232-248, 1964

6）塚田一博, 霜田光義, 坂東 正他：Hassab 手術. 手術 $52: 1155-1159,1998$

7）高瀬靖広，中原 朗：食道静脈瘤出血に対する内 視鏡的塞栓療法. Prog Digest Endosc 消内視鏡の 進步 $13: 34-37,1978$

8) 坂東 正, 岸本浩史, 塚田一博: 開胸経横隔膜的 脾臟摘出術。手術 $58: 709-713,2004$

9）中村俊也，藤野雅之：食道胃静脈瘤内視鏡治療と 長期予後. 日門脈圧穴進症会誌 $6: 218-221$, 2000

10）坂東 正，津田祐子，岸本浩史他：食道胃静脈㿇 の長期予後一治療後 10 年以上経過症例の検討一. 日門脈圧六進症会誌 $7: 218-222,2001$ 


\title{
A COMPARISON STUDY OF THORACO-TRANSPHRENIC PROCEDURE AND CONVENTIONAL LAPAROTOMY IN HASSAB OPERATION
}

\author{
Tadashi BANDO, Takuya NAGATA, Fuminori YAMAGISHI and Kazuhiro TSUKADA \\ Second Department of Surgery, Toyama University School of Medicine
}

We report a comparison study of Hassab operations for esophagogastric varices by thoraco-transphrenic procedure (TTP) and abdominal procedure (AP). Subjects were 13 patients operated on by TTP from 2000 to 2003 (TTP group), and they were compared with another 22 patients operated on by AP in the same period (AP group). The operation time was significantly prolonged in the TTP group. Intraoperative blood loss and blood transfusion were significantly little in the TTP group. No significant difference in the weight of the removed spleen was noted between two groups, showing that the huge spleen did not restrict the transphrenic procedure. A moderate grade complication was recognized in 3 cases $(23.1 \%)$ in the TTP group, but there was no significant difference in the morbidity between two groups. No severe complications occurred in both groups. The mean postoperative hospital stay of TTP group was 31 days which was shorter than that of AP group. There was no difference between two groups in the effects on liver function that was assessed by changes in the serum bilirubin level. It was considered that the aggressive insult of TTP was slight from the changes in the postoperative white blood cell count and IL-6 level. The cumulative relapse rate in the TTP group was $9.1 \%$ which was slightly lower than $22.3 \%$ in the AP group after the operation for five years. In conclusion the Hassab operation by TTP was safer and more effective than that by AP. 